\title{
Jurist-Diction
}

Volume 1 No. 1, September 2018

Article history: Submitted 3 August 2018; Accepted 15 August 2018; Available online 3 September 2018

\section{ASPEK-ASPEK HUKUM DALAM PENERBANGAN CODESHARE INTERNASIONAL DAN DOMESTIK DI INDONESIA}

\author{
Alfan Zakiyanto \\ Azakiyanto@gmail.com \\ Universitas Airlangga
}

\begin{abstract}
Airlines, entities that operate on the transportation business, need to reach the widest possible region to be able to serve wider market and achieve the highest income possible. An airline needs to pay a high cost to broaden it's reach. There are also borders that can't be overcame based on the applied international air law. Thus, in practice, cooperation mechanisms arise in the form of codeshare where an airline, as the contracting carrier. sells tickets of flights operated by another airline, as the actual carrier, with the contracting carrier's flight code. Such cooperations are applied in international and domestic routes. In regard to the fact that actual carriers don t have any direct agreement with the passengers, changes to the liability in case of losses received by the passengers of domestic and international codeshared flights were found, compared to non-codeshared flights, along with the legal remedies available to resolve such dispute.
\end{abstract}

Keywords: Codeshare; Flight Compensation; Aviation Liability; Actual Carrier; Contracting Carrier.

\begin{abstract}
Abstrak
Maskapai selaku entitas yang bergerak pada usaha transportsi udara perlu menjangkau wilayah yang seluas mungkin untuk dapat melayani pangsa pasar yang luas dan mendapatkan keuntungan semaksimal mungkin. Adapun untuk memperluas jangkauannya, diperlukan biaya dalam bilangan yang tidak sedikit. Disamping itu juga terdapat batasan-batasan yang tidak dapat dilewati dalam hukum internasional yang berlaku. Sehingga, dalam praktiknya timbul suatu mekanisme kerjasama dalam bentuk perjanjian antar maskapai dalam bentuk codeshare dimana suatu maskapai (contracting carrier) dapat menjual tiket untuk suatu penerbangan yang dioperasikan oleh maskapai lain (actual carrier) dengan nomor penerbangan maskapai penjual tiket tersebut. Kerjasama tersebut dapat ditemukan pada penerbangan yang dilakukan dengan rute internasional dan domestik. Adapun dengan adanya maskapai operator yang tidak memiliki perjanjian secara langsung dengan pengangkut menyebabkan adanya perubahaan pada tanggung gugat dalam adanya kerugian yang diterima oleh penumpang pada penerbangan codeshare internasional dan domestik serta bagaimana upaya yang dapat dilakukan untuk menyelesaikan sengketa ganti rugi tersebut.
\end{abstract}

Kata Kunci: Codeshare; Ganti Rugi Penerbangan; Tanggung Gugat Penerbangan; Actual Carrier; Contracting Carrier.

\section{Pendahuluan}

Chicago Convention 1944 on International Civil Aviation yang mengatur tentang Penerbangan Sipil Internasional memberikan banyak prinsip dasar mengenai penerbangan sipil internasional. Di dalam Konvensi Chicago Pasal 1 telah disebutkan suatu prinsip yang berarti setiap negara anggotanya memiliki kedaulatan penuh dan 
eksklusif atas wilayah udara di atas wilayahnya. ${ }^{1}$ Sehingga dapat dimaknai dari prinsip tersebut bahwa wilayah udara suatu negara bersifat tertutup. Berkaitan dengan itu, muncullah konsep bahwa perlu dilakukan pemberian sembilan freedoms of the air yang merupakan hak bagi pesawat sipil dengan suatu kebangsaan yang berbeda untuk terbang, mengangkut, atau mendarat dari atau ke negara lain.

Pemberian hak tersebut juga diwajibkan oleh Pasal 6 Konvensi Chicago 1944 yang menyatakan bahwa tidak diperbolehkan bagi suatu pesawat berkebangsaan lain untuk melintasi atau menuju wilayah negara yang berbeda dengan negara kebangsaannya kecuali dengan izin khusus dari negara kolong wilayah udara tersebut. ${ }^{2}$ Hak-hak tersebut diberikan oleh negara dalam bentuk perjanjianperjanjian, secara bilateral dan multilateral. Sehingga, bagi suatu pesawat untuk bisat untuk melintas, mengangkut, atau mendarat dari atau ke suatu negara yang berbeda dengan kebangsaannya, diperlukan perjanjian antar negara mengenai pemberian hak yang dikenal sebagai freedoms of the air. ${ }^{3}$

Industri penerbangan terus berkembang tanpa henti. Perkembangan tersebut menimbulkan skema-skema kerjasama yang memiliki potensi untuk suatu maskapai dapat beroperasi dalam rute yang dilarang berdasarkan Air Service Agreement yang berlaku, termasuk rute cabotage. Adapun salah satu hasil dari kerjasama tersebut adalah munculnya skema codeshare yang merupakan terminologi bisnis dimana ada penggunaan kode nomor penerbangan suatu maskapai untuk mengidentifikasi penerbangan sipil yang dioperasikan oleh maskapai lain pada tiket penumpang, sistem reservasi komputer, panduan-panduan maskapai, dan papan informasi bandara. ${ }^{4}$ Kerjasama dengan bentuk codeshare memungkinkan maskapai untuk terbang melalui jalur-jalur yang sebelumnya tidak dimungkinkan dikarenakan adanya batasan-batasan yang timbul dari Pasal 7 Konvensi Chicago 1944 maupun

\footnotetext{
${ }^{1}$ Convention on International Civil Aviation 1944, Opened for Signature 7 Desember 1944, 15 UNTS 295 (entered into force 4 April 1947) Ps. 1.

2 Ibid Ps. 6

3 Pablo Mendes de Leon dan IH.H.Ph. Diederiks-Verschoor, An Introduction to Air Law: 9th Revised Edition, The Netherlands: Kluwer Law International, 2012, [53].

4 Morandi, V., et al, Codesharing agreements by low-cost carriers: An explorative analysis. Journal of Air Transport Management, 42, 2015.[184-191].
} 
memungkinkan maskapai untuk menjalankan usaha pengangkutan udaranya dengan lebih efektif dan efisien.

Dalam keadaan penerbangan bukan codeshare, tanggung gugat yang timbul dari kontrak antara maskapai dan penumpang terbilang sederhana dikarenakan pihak yang terlibat, secara faktual dan secara yuridis, terbatas antara maskapai dan penumpang. Namun hal yang demikian tidak sama dengan penerbangan codeshare yang memiliki pihak yang berbeda, yakni actual carrier (maskapai pelaksana penerbangan) dan contracting carrier (maskapai yang menjual tiket penerbangan). Dengan demikian, jurnal ini akan membahas mengenai tanggung gugat dalam penerbangan codeshare baik yang dilakukan secara internasional maupun domestik di Indonesia.

\section{Penerbangan Codeshare Internasional}

Angkutan udara internasional adalah angkutan udara di mana tempat keberangkatan dan tempat tujuannya berada dalam dua wilayah negara yang berbeda atau dalam satu wilayah negara yang sama dengan pemberhentian pada wilayah negara lain. ${ }^{5}$ Dalam pelaksanaan angkutan udara internasional, maskapaimaskapai melakukan kerjasama antar maskapai dalam berbagai macam bentuk. Salah satu bentuk kerjasama yang umum dilakukan adalah kerjasama dalam bentuk perjanjian codeshare. Dalam International Civil Aviation (ICAO) Manual on the Regulation of International Air Transport terdapat definisi penerbangan codeshare yang berbunyi sebagai berikut.

"the use of the flight designator code of one carrier on a service performed by a second air carrier, which service is usually also identified (and may be required to be identified) as a service of, and being performed by, the second air carrier"6

Atau penggunaan kode penerbangan suatu pengangkut atas jasa yang dilakukan oleh pengangkut udara kedua, yang mana jasa tersebut juga diidedntifikasi sebagai jasa

\footnotetext{
5 Convention for the Unification of Certain Rules for International Carriage by Air, Opened for Signature 28 Juli 1999, 2242 UNTS 309 (entered into force 4 November 2003) Art. 1 (2).

6 ICAO, 'Doc 9626 - Manual on the Regulation of International Air Transport', (Selanjutnya disebut sebagai ICAO I), h. [4].1-7.
} 
pengangkut udara kedua. Penerbangan codeshare itu sendiri juga perlu diperjanjikan dalam Air Service Agreement antar negara dalam bentuk commercial opportunities. ${ }^{7}$

\section{Rute Penerbangan Codeshare}

Rute penerbangan codeshare dapat dilakukan pada penerbangan domestik maupun internasional. Secara umum, rute yang dijadikan pilihan oleh maskapai untuk diperjanjikan dalam codeshare bertujuan untuk memperluas atau memperkuat rute yang sudah dilayani sebelumnya. Secara khusus, tiap rute yang diperjanjikan oleh maskapai dalam perjanjian codeshare dilakukan untuk mencapai tujuan yang bervariasi tiap perjanjiannya. Jenis-jenis rute yang diperjanjikan dalam perjanjian codeshare dapat digolongkan menjadi tiga sebagai berikut. ${ }^{8}$

- Parallel Operation on A Trunk Route: Keadaan dimana kedua maskapai beroperasi pada rute yang sama dan saling menjual tiket pesawat yang dioperasikan oleh maskapai satu sama lain dengan kode penerbangannya masing-masing contracting carrier.

- Unilateral Operation on A Trunk Route: Keadaan dimana hanya actual carrier yang beroperasi pada rute tersebut dan contracting carrier menjual tiket dengan kode penerbangannya sendiri.

- Behind and Beyond Route: Keadaan dimana contracting carrier menjual tiket dari penerbangan suatu actual carrier agar dapat mencapai tujuan akhir dengan connecting flight yang dioperasikan oleh actual carrier.

\section{Pengendalian Inventaris dalam Penerbangan Codeshare}

Perjanjian codeshare mensyaratkan adanya penjualan tiket penerbangan yang dioperasikan actual carrier oleh contracting carrier. Mekanisme penentuan tiket yang dapat dijual oleh contracting carrier maupun oleh actual carrier sendiri secara khusus dapat digolongkan menjadi dua. Adapun dua golongan pengendalian inventaris tersebut adalah sebagai berikut. ${ }^{9}$

- Free-sale codeshare agreement:

7 Pablo Mendes de Leon.Op.Cit.[24].

8 Arpad Szakall, "Interline and Code-share Agreements", http://www.aviationlaw.eu/wp/ wp-content/uploads/2013/09/Interline-and-code-share-agreements.pdf, dikunjungi pada tanggal 4 Mei 2018.

9 Steed Davis Gleave Op.Cit.[8]. 
Contracting carrier memiliki wewenang untuk menjual tiket pesawat sejumlah berapapun yang dapat dijual oleh contracting carrier tanpa ada batas minimum atatu maksimum apapun. Pada bentuk pembagian tempat ini, actual carrier memiliki resiko yang lebih tinggi mengingat sifat kerjasama yang tidak memiliki kepastian dan contracting carrier memiliki sifat serupa dengan agen.

- Blocked space codeshare agreement:

Blocked space codeshare agreement dimulai dari alokasi jumlah tiket yang dapat dijual oleh contracting carrier dalam penerbangan yang dioperasikan actual carrier. Pada praktiknya, blocked space codeshare agreement dapat dibagi menjadi dua yakni soft dan hard blocked space codeshare agreement. Dalam hard blocked space codeshare agreement, actual carrier dan contracting carrier memiliki risiko yang sama terhadap penjualan kursi penumpang yang sudah diperjanjikan sebelumnya. Sedangkan dalam soft blocked space codeshare agreement, masih dimungkinkan untuk contracting carrier untuk mengembalikan kursi yang tidak terjual, sehingga dapat mengurangi risiko yang ditanggung oleh contracting carrier.

\section{Pihak yang bertanggung gugat dalam penerbangan codeshare internasional}

Konvensi Montreal 1999 mendefinisikan contracting carrier sebagai maskapai yang memperbolehkan maskapai lain untuk melakukan pengangkutan atas namanya. ${ }^{10}$ Sedangkan actual carrier adalah maskapai yang melakukan pengangkutan tersebut. ${ }^{11}$ Di samping itu, Konvensi Montreal 1999 juga menentukan tanggung gugat dari masing-masing pihak tersebut yakni terhadap seluruh kewajiban yang muncul dari kontrak bagi contractual carrier, dan terbatas pada penerbangan yang dilakukannya bagi actual carrier. ${ }^{12}$

Konvensi Montreal 1999 Pasal 45 menjelaskan secara rinci bahwa gugatan dapat diajukan oleh penggugat kepada actual carrier maupun pada

${ }^{10}$ Convention for the Unification of Certain Rules for International Carriage by Air, Opened for Signature 28 Juli 1999, 2242 UNTS 309 (entered into force 4 November 2003) Art..41

11 ibid

12 Ibid ps. 40 
contracting carrier baik secara sendiri-sendiri maupun bersama-sama. ${ }^{13}$ Adapun apabila penggugat hanya menyampaikan gugatan kepada salah satu dari kedua maskapai tersebut, maka tergugat dapat meminta maskapai lainnya untuk ikut serta dalam proses perkara, seluruh prosedurnya, serta efek-efek yang timbul dari penyelesaian sengketa tersebut. ${ }^{14}$

Sebagai contoh, apabila terdapat gugatan ganti rugi pada Garuda Indonesia sebagai actual carrier mengenai penerbangan codeshare yang dilakukannya dengan KLM sebagai contracting carrier, maka gugatan dapat dilakukan pada pengadilan Indonesia mengingat Indonesia telah meratifikasi Konvensi Montreal 1999 melalui Peraturan Presiden RI Nomor: 95 tahun 2016 tanggal 21 November 2016 tentang Pengesahan Konvensi Unifikasi Aturan-Aturan Tertentu Tentang Angkutan Udara Internasional. ${ }^{15}$ Dalam keadaan tersebut, Garuda Indoensia dapat meminta kesertaan KLM sebagai salah satu pihak pada penyelesaian sengketa mengingat Hukum Acara Perdata Indonesia, memungkinkan tergugat untuk melakukan eksespsi kekeliruan pihak (Error in Persona) dengan bentuk kurang pihak (Plurium Litis Consortium) ${ }^{16}$ sekalipun penggugat hanya mengajukan gugatan kepada Garuda Indonesia tanpa menyertakan KLM sebagai tergugat II.

\section{Jurisdiksi yang Berlaku dalam Penyelesaian Ganti Rugi Codeshare Internasional}

Dalam Konvensi Montreal 1999, ada beberapa kriteria untuk suatu negara dapat memberlakukan jurisdiksinya dalam suatu penerbangan. Adapun kriteriakriteria tersebut adalah: ${ }^{17}$ (i) Negara tempat adanya kantor perusahaan pengangkut, (ii) Negara tempat kantor pusat perusahaan pengangkut, (iii) Negara tempat kontrak

\footnotetext{
${ }^{13}$ Ibid, ps. 45 .

${ }^{14}$ Ibid.

${ }^{15}$ Kementerian Perhubungan Indonesia, "Ratifikasi Konvensi Montreal (MC) 1999, Indonesia Meningkatkan Daya Tawar di Penerbangan Internasional”, http://hubud.dephub.go.id/?id/news/ detail/3019, 16 Februari 2017, dikunjungi pada tanggal 30 Juni 2018.

${ }^{16}$ M. Yahya Harahap S.H., HUKUM ACARA PERDATA: Gugatan, Persidangan, Penyitaan, Pembuktian, dan Putusan Pengadilan, Jakarta, Sinar Grafika, 2009.[439].

${ }^{17}$ Convention for the Unification of Certain Rules for International Carriage by Air, Opened for Signature 28 Juli 1999, 2242 UNTS 309 (entered into force 4 November 2003) Art. 33 paragaraf 1.
} 
dibuat, dan (iv) Negara tempat tujuan akhir penerbangan. Kriteria-kriteria tersebut sama persis dengan yang telah dibelakukan oleh Konvensi Warsawa 1929 pada Pasal 28 ayat (1) dengan tambahan kriteria ke-5 yakni (v) negara tempat penumpang berdomisili. ${ }^{18}$ Kriteria-kriteria tersebut berlaku secara alternatif, sehingga dapat disimpulkan bahwa apabila penumpang atau penggugat dapat melakukan gugatan ganti rugi di pengadilan negeri dimana kriteria-kriteria tersebut terpenuhi.

Namun, dalam penerbangan codeshare, pemaknaan kriteria pertama dan kedua (negara tempat adanya kantor perusahaan pengangkut dan negara tempat kantor pusat perusahaan pengankut) memerlukan penafsiran lebih dalam. Hal ini dikarenakan keadaan pada penerbangan yang dilakukan secara codeshare terdapat dua perusahaan pengankut yang berhubungan dengan seorang penumpang, yakni contracting carrier dan actual carrier, sesuai dengan Pasal 39 Konvensi Montreal 1999. Sehingga Konvensi Monteral 1999 memberikan perluasan atas jurisdiksi pertama dan kedua, seperti yang telah disebutkan dalam Pasal 33 paragraf 1 Konvensi Montreal 1999.

Pengaturan tersebut muncul dalam Pasal 46 tentang "additional jurisdiction" yang menyatakan bahwa gugatan dapat diajukan di negara tempat adanya kantor pusat mupun cabang dari actual carrier. Sehingga dapat disimpulkan, dalam hal adanya kerugian dan kerusakan yang dilindungi Konvensi Montreal 1999 pada penerbangan codeshare, penggugat dapat menggugat ke negara tempat adanya kantor pusat maupun cabang dari contracting carrier maupun operating carrier.

\section{Konsep dan Nilai Tanggung Gugat Codeshare Internasional}

Kontrak antara penumpang dan maskapai yang bersifat kontrak konsumen yang merupakan kontrak baku yang disajikan oleh maskapai hanya untuk disetujui oleh penumpang dan tidak untuk dinegosiasikan (as is clause). ${ }^{19}$ Keadaan tersebut menyebabkan adanya kesulitan bagi penumpang untuk membuktikan

\footnotetext{
${ }^{18}$ Ibid ps 33 paragraf 2.

${ }_{19}$ Agus Yudha Hernoko, Hukum Perjanjian: Asas Proporsionalitas dalam Kontrak Komersial, Jakarta, Kencana Prenada Group, 2009.[2]
} 
adanya kesalahan maskapai mengingat adanya keterbatasan kemampuan teknis penumpang yang berkaitan dengan penerbangan tersebut. Sehingga, Konvensi Montreal 1999 perlu membentuk pengaturan yang menyeimbangkan posisi dari penumpang dan maskapai. Akibatnya, beban pembuktian dari permohonan ganti rugi kepada maskapai oleh penumpang bersifat terbalik, dimana penumpang hanya dibebankan pembuktian kerugian dan maskapai yang perlu membuktikan bahwa maskapai tidak melakukan kesalahan. ${ }^{20}$

Konvensi Montreal 1999 juga memberlakukan konsep unlimited liability dimana maskapai memiliki tanggung gugat dengan nilai tidak terbatas. ${ }^{21} \mathrm{Hal}$ ini telah dijelaskan dalam tanggung gugat maskapai yang bersifat dua tingkat (two-tier) untuk kerugian-kerugian kematian atau bodily injury dalam Pasal 21 Konvensi Montreal 1999. ${ }^{22}$ Adapun dua tingkat tersebut ditentukan berdasarkan nilainya yang berada di atas atau di bawah 113.000 SDRs. ${ }^{23}$ Masing-masing tingkatan bersifat sebagai berikut.

- Di bawah 113.000 SDR:

Tanggung gugat pada tingkat ini memiliki sifat strict liablity dimana maskapai bertanggung gugatmelakukan pembayaran ganti rugi sesuai dengan kerugian yang diderita oleh penggugat. ${ }^{24}$ Namun, Konvensi Montreal 1999 juga memberikan perlindungan pada maskapai dengan ketentuan bahwa maskapai masih dapat mengecualikan dirinya, seluruhnya atau sebagaian, dari tanggung gugat tersebut apabila kerugian disebabkan oleh penumpang, keseluruhan atau sebagian ${ }^{25}$

- Di atas 113.000 SDR:

Pada tingkat kedua ini, maskapai juga wajib melakukan pembayaran ganti rugi kepada penumpang atas kerugian yang diterimanya dalam penerbangan

\footnotetext{
${ }^{20}$ Convention for the Unification of Certain Rules for International Carriage by Air, Opened for Signature 28 Juli 1999, 2242 UNTS 309 (entered into force 4 November 2003) Art. 20, ps. 21(2)

${ }^{21}$ Pablo Mendes de Leon Op Cit.[225].

${ }^{22}$ Convention for the Unification of Certain Rules for International Carriage by Air, Opened for Signature 28 Juli 1999, 2242 UNTS 309 (entered into force 4 November 2003) Art.. 21

${ }^{23}$ Nilai 100.000 SDRs pada Pasal 21 Konvensi Montreal 1999 telah ditingkatkan menjadi 113.100 SDR sejak 1 Januari 2010 melalui ICAO Council - 188th session sesuai dengan pasal 24 Konvensi Montreal 1999.

${ }^{24}$ Convention for the Unification of Certain Rules for International Carriage by Air, Opened for Signature 28 Juli 1999, 2242 UNTS 309 (entered into force 4 November 2003) Art. 21(1)

${ }^{25}$ Ibid ps. 20.
} 
tersebut. Namun, maskapai lebih dipermudah dalam pengecualian dirinya dari tanggung gugat tersebut. ${ }^{26}$ Kemudahan tersebut adalah adanya tiga alasan bagi maskapai mengecualikan dirinya dari tanggung gugat tersebut, yakni (i) terdapat kontribusi penumpang dalam penyebab adanya kerugian, ${ }^{27}$ (ii) Kerugian bukan disebabkan dari kelalaian atau wrongful act atau omission dari maskapai, pegawai, dan agennya, ${ }^{28}$ dan (iii) Kerugian timbul sepenuhnya dari kelalaian atau wrongful act atau omission dari pihak ketiga. ${ }^{29}$

Di samping itu, Konvensi Montreal 1999 mengatur pengaturan tanggung gugat untuk kerugian dalam bentuk keterlambatan (delay), barang bagasi, dan kargo berlaku konsep limited liability dengan nilai masing masing 4694 SDR, 1131 SDR, dan $19 \mathrm{SDR} / \mathrm{Kg} .{ }^{30}$ Pembayaran ganti rugi atas kematian atau luka terhadap penumpang dapat dibayarkan sebagian sebagai immediate payment yang bertujuan untuk memenuhi kebutuhan ekonomi penumpang. ${ }^{31}$ Pembayaran tersebut nantinya akan dianggap sebagai bagian dari pembayaran ganti rugi secara keseluruhan.

\section{Penerbangan Codeshare dalam Hukum Penerbangan Domestik Indonesia}

UU Penerbangan mengatur banyak aspek ekonomi dari penerbangan dalam Pasal 83 hingga Pasal 138, di dalamnya terdapat pengaturan mengenai angkutan udara niaga, pelayanan angkutan udara niaga berjadwal, angkutan udara bukan niaga, dan lain sebagainya. ${ }^{32}$ Berdasarkan UU Penerbangan, pengangkutan udara

26 Thomas J Whalen. 'The New Warsaw Convention: The Montreal Convention', The Air andSpaceLaw,Vol25,No1;2000,h.19<https://heinonline.org/HOL/LandingPage?handle=hein.kluwer/airlaw0025\&div $=6 \&$ id $=\&$ page $>$.

${ }^{27}$ Convention for the Unification of Certain Rules for International Carriage by Air, Opened for Signature 28 Juli 1999, 2242 UNTS 309 (entered into force 4 November 2003) Art.. 20 seperti yang telah disesuaikan dengan ICAO, "Revision of limits of liability under the Montreal Convention of 1999", Ref. LE 3/38.1-09/87.

${ }^{28}$ Ibid ps. 21(2)(a).

${ }^{29}$ Ibid ps. 21(2)(b).

${ }^{30}$ Ibid ps. 22.

${ }^{31}$ Convention for the Unification of Certain Rules for International Carriage by Air, Opened for Signature 28 Juli 1999, 2242 UNTS 309 (entered into force 4 November 2003) Art.. 28

${ }^{32}$ H.K Martono dan Ahmad Sudiro, Hukum Udara Nasional Dan Internasional Publik, Jakarta, Rajawali Pers, 2012, (selanjutnya disingkat H.K. Martono I).[234]. 
dalam negeri sendiri memiliki definisi sebagai berikut. ${ }^{33}$

"Angkutan Udara Dalam Negeri adalah kegiatan angkutan udara niaga untuk melayani angkutan udara dari satu bandar udara ke bandar udara lain di dalam wilayah Negara Kesatuan Republik Indonesia."

Adapun pengangkutan udara dalam negeri sendiri terbagi menjadi dua, yakni yang dilakukan secara berjadwal dan secara tidak berjadwal. ${ }^{34}$ Seperti yang berlaku pada penerbangan codeshare internasional, penerbangan codeshare yang dilakukan secara domestik diberlakukan hanya pada penerbangan niaga berjadwal.

\section{Praktik Penerbangan Codeshare Domestik Inodnesia}

Penerbangan codeshare secara domestik di Indonesia pada praktiknya masih belum diberlakukan. Namun dapat diperkirakan dalam waktu dekat akan dimulai penerbangan codeshare secara domestik yang akan dilakukan oleh Garuda Indonesia dan Sriwijaya Air. Adapun rute-rute yang hendak diperjanjikan oleh kedua maskapai tersebut adalah rute yang hanya dioperasikan oleh salah satu dari kedua maskapai pihak perjanjian codeshare (unilateral operation on a trunk route), serta rute yang ditujukan untuk memperkuat jangkauan dari penerbangan yang sebelumnya sudah dioperasikan oleh Garuda Indonesia maupun Sriwijaya Air (behind and beyond route). ${ }^{35}$

Perjanjian codeshare yang dilakukan secara domestik di Indonesia memiliki kerumitan tersendiri, hal ini dikarenakan adanya tingkatan maskapai berdasarkan standar pelayanan yang diberikan. Perbedaan pelayanan tersebut dapat digolongkan menjadi tiga berdasarkan standar layanan yang diberikan yakni standar maksimum (full services), menengah (medium services), dan minimum (no frills). Terhadap jenis layanan tersebut, pengangkut wajib memberitahukan kondisi dan spesifikasi

33 Undang-Undang Nomor 1 Tahun 2009 tentang Penerbangan (Lembaran Negara Tahun 2009 Nomor 1, Tambahan Lembaran Negara Republik Indonesia Nomor 4956), Ps. 1 angka 16.

34 Ibid Ps. 83 ayat (3)

35 Dina Mirayanti Hutauruk, "Garuda Indonesia dan Sriwijaya Air Group Sepakati Kerjasama Codeshare", <http:/www.tribunnews.com/bisnis/2018/05/17/garuda-indonesia-dan-sriwijaya-air-group-sepakati-kerjasama-codeshare?page=all $>$, 17 Mei 2018, diakses pada tanggal 1 Juli 2018. 
pelayanan yang diberikan kepada penumpang. ${ }^{36}$

Perbedaan jenis layanan dalam perjanjian codeshare menjadi hal yang perlu diperhatikan. Sebagai contoh, pada perjanjian codeshare yang akan dilakukan oleh Garuda Indonesia dan Sriwijaya Air tersebut terdapat perbedaan standar pelayanan yang diberikan oleh kedua maskapai tersebut. Garuda Indonesia merupakan maskapai full service sedangkan Sriwijaya Air merupakan maskapai medium services.

Penulis berpendapat bahwa perjanjian codeshare untuk rute domestik yang diperjanjikan oleh Garuda Indonesia dan Sriwijaya Air tersebut tetap dapat dilaksanakan. Hal ini hanya dapat dimungkinkan apabila terdapat penyampaian bahwa penerbangan codeshare tersebut tidak dilakukan oleh contracting carrier namun oleh operating carrier. Dengan penyampaian tersebut, maka penumpang dapat menerima informasi mengenai conditions of carriage yang berlaku serta standar pelayanan yang diberikan oleh pengangkut. Berkaitan dengan itu, Garuda Indonesia serta Sriwijaya Air perlu menjelaskan ketentuan yang berlaku dimana ada penerbangan codeshare, khususnya saat pengangkut berperan sebagai contracting carrier.

\section{Pihak yang Bertanggung Gugat dalam Penerbangan Codeshare Domestik Indonesia}

UU Penerbangan Indonesia mengatur penerbangan codeshare pada Pasal 183 UU Penerbangan yang mengatur tentang Tanggung Jawab Pengangkut Lain. Namun, pemisahan actual carrier dan contracting carrier seperti yang diatur pada Konvensi Montreal 1999 tidak dapat ditemukan pada pada batang tubuh UU Penerbangan Indonesia. Penjelasan akan actual carrier dan contracting carrier hanya dapat ditemukan pada penjelasan Pasal 183 UU Penerbangan yang berbunyi sebagai berikut.

"Yang dimaksud "pihak pengangkut lain" adalah biro/agen perjalanan atau perusahaan ekspedisi muatan pesawat udara yang bertindak sebagai pembuat kontrak pengangkutan (contracting carrier) dengan penumpang atau pengirim barang atau dengan seseorang yang bertindak atas nama penumpang atau

36 Undang-Undang Nomor 1 Tahun 2009 tentang Penerbangan (Lembaran Negara Tahun 2009 Nomor 1, Tambahan Lembaran Negara Republik Indonesia Nomor 4956) Ps. 97 ayat (5). 
pengirim barang untuk diangkut oleh perusahaan angkutan udara (actual carrier). ${ }^{37}$

Pada penjelasan tersebut, tidak disebutkan bahwa Badan Usaha Angkutan udara dapat dianggap sebagai contracting carrier. Namun penulis disini berpendapat bahwa penerbangan codeshare merupakan suatu "angkutan yang dilakukan oleh pengangkut lain" seperti yang dimaksud oleh Pasal 183 UU Penerbangan dikarenakan definisi yang sesuai dengan keadaan penerbangan codeshare dimana contracting carrier melakukan penerbangan yang disubtitusikan kepada actual carrier pada pelaksanaannya. Hal ini juga ditekankan oleh keadaan dimana penjelasan suatu peraturan perundang-undangan tidak dapat mempersempit makna dari batang tubuh peraturan perundang-undangnya. ${ }^{38}$ Adapun Pasal 183 UU Penerbangan itu sendiri hanya mengatur bahwa tanggung gugat seperti yang diatur dalam Pasal 141, Pasal 143, Pasal 144, Pasal 145, dan Pasal 146 juga berlaku pada penerbangan codeshare. ${ }^{39}$ Namun Pasal 183 tidak memberikan penjelasan lebih lanjut mengenai pihak yang bertanggung gugat pada penerbangan tersebut.

Peraturan Menteri Perhubungan Nomor 77 Tahun 2011 tentang Tanggung Jawab Pengangkut Angkutan Udara (Permenhub No. 77 tahun 2011) merupakan salah satu peraturan pelaksana dari UU Penerbangan. Pasal 2 Permenhub No. 77 tahun 2011 menyebutkan kerugian apa saja yang menjadi tanggung gugat dari pengangkut yang mengoperasikan pesawat udara. Adapun kerugian-kerugian yang menjadi tanggung gugat actual carrier tersebut adalah: ${ }^{40}$

a. Penumpang yang meninggal dunia, cacat tetap atau luka-luka;

b. Hilang atau rusaknya bagasi kabin;

c. Hilang, musnah, atau rusaknya bagasi tercatat;

d. Hilang, musnah, atau rusaknya kargo;

${ }^{37}$ Penjelasan Undang-Undang Nomor 1 Tahun 2009 tentang Penerbangan (Lembaran Negara Tahun 2009 Nomor 1, Tambahan Lembaran Negara Republik Indonesia Nomor 4956), Ps. 183.

${ }^{38}$ Klinik Hukumonline, "Kekuatan Hukum Penjelasan atas Undang Undang”, <http://www. hukumonline.com/klinik/detail/cl3276/kekuatan-hukum-penjelasan-atas-undang-undang>, 30 Januari 2012, diakses pada tanggal 3 Juli 2018.

39 Undang-Undang Nomor 1 Tahun 2009 tentang Penerbangan (Lembaran Negara Tahun 2009 Nomor 1, Tambahan Lembaran Negara Republik Indonesia Nomor 4956), Ps. 183.

${ }^{40}$ Peraturan Menteri Perhubungan Nomor 77 tahun 2011 tentang Tanggung Jawab Pengangkut Angkutan Udara (Berita Negara Republik Indonesia Tahun 2011 Nomor 486) Ps. 2. 
e. Keterlambatan angkutan udara; dan

f. Kerugian yang diderita oleh pihak ketiga.

Kerugian kerugain tersebut merupakan kerugian-kerugian yang diatur secara umum oleh UU Penerbangan (Pasal 141 hinga Pasal 146 UU Penerbangan). Adanya Pasal 2 tersebut memberikan penjelasan bahwa penggugat dapat mengajukan gugatannya kepada actual carrier dan bukan pada contracting carrier. Adanya tanggung gugat pada actual carrier dan bukan contracting carrier ini dipertegas oleh Pasal 21 ayat (2) dari Permenhub No. 7 tahun 2011 yang berbunyi sebagai berikut. ${ }^{41}$

"Pemberian ganti kerugian sebagaimana dimaksud pada ayat (1) diajukan kepada pengangkut yang secara nyata melakukan pengangkutan udara (actual carrier), apabila pengangkutan udara tersebut dilakukan lebih dari satu Badan Usaha Angkutan Udara."

Sehingga dapat disimpulkan bahwa Permenhub No. 7 tahun 2011 mengatur bahwa pihak yang bertanggung gugat pada penerbangan codeshare domestik adalah actual carrier, bukan contracting carrier.

\section{Konsep Tanggung Gugat Penerbangan Codeshare Domestik}

Penumpang sebagai pelanggan memiliki posisi yang lebih rendah dikarenakan kurang adanya pengetahuan mengenai pemenuhan kewajiban oleh maskapai. Dengan keadaan yang demikian tersebut, terdapat tiga konsep tanggung gugat yang ada dalam UU Penerbangan. Adapun masing-masingnya dapat ditemukan pada Pasal-Pasal tertentu pada UU Penerbangan seperti berikut.

- Tanggung gugat atas dasar kesalahan (based on fault liability):

Pasal 143 UU Penerbangan telah mengatur bahwa pengangkut tidak bertanggung gugat atas kerugian dalam bentuk hilang atau rusaknya bagasi kabin, kecuali apabila kerugian tersebut disebabkan oleh tindakan pengangkut atau orang yang dipekerjakannya. ${ }^{42}$ Sehingga dapat disimpulkan bahwa untuk tanggung gugat atas kerugian dalam bentuk kehilangan atau kerusakan bagasi

${ }^{41}$ Ibid Ps. 21 (2).

42 Undang-Undang Nomor 1 Tahun 2009 tentang Penerbangan (Lembaran Negara Tahun 2009 Nomor 1, Tambahan Lembaran Negara Republik Indonesia Nomor 4956), Ps. 143 
kabin, terdapat tiga elemen yang perlu dipenuhi secara kumulatif yakni sebagai berikut. (i) adanya kesalahan pengangkut atau orang yang dipekerjakannya; (2) adanya kerugian; (3) adanya hubungan kausalitas antara kekhilafan dan kerugian tesebut. ${ }^{43}$ Penumpang wajib membuktikan ketiga element tersebut dalam gugatannya. Konsep ini sebenarnya sulit untuk diterapkan karena kedudukan penumpang dan pengangkut tidak berimbang. ${ }^{44}$

- Tanggung gugat praduga bersalah (presumption of liability):

Tanggung gugat praduga bersalah pada hukum pengangkutan udara adalah keadaan dimana pengangkut dianggap bersalah atas kerugian yang diderita penumpang dan wajib melakukan ganti rugi atas kerugian tersebut. Namun anggapan tersebut dapat ditolak oleh pengangkut untuk membebaskan dirinya dari tanggung gugat tersebut.

Sehingga dapat disimpulkan bahwa penggungat tidak perlu melakukan pembuktian kesalahan pengangkut pada gugatan ganti ruginya, namun hanya perlu melakukan pembuktian kerugian yang dideritanya. Berkaitan dengan itu, pengangkut masih dapat mengecualikan diri dari tanggung gugat tersebut dengan membuktikan bahwa kesalahan yang menyebabkan kerugian tersebut bukanlah timbul dari pengangkut. Pembuktian seperti ini sering dikenal sebagai beban pembuktian negatif atau beban pembuktian terbalik (reversed burden of proof). Konsep seperti ini diberlakukan karena dirasa sulit bagi penumpang untuk membuktikan kesalahan pengangkut dikarenakan tidak adanya kemampuan untuk membuktikan dengan teknologi yang dimiliki. ${ }^{45}$

Ketentuan tanggung gugat yang demikian juga ditemukan pada UU Penerbangan. Pasal 146 UU Penerbangan yang mengatur bahwa Pengangkut bertanggung jawab atas kerugian yang diderita karena keterlambatan pada

\footnotetext{
${ }^{43}$ Annalisa Yahanan Norsuhaida Che Musa dan Kamal Halili Hasan, 'Tanggung Jawab Pengangkut Udara Terhadap Penumpang', Mimbar Hukum, Vol 22, No. 2; 2010, h. 247 <fhttps://journal.ugm.ac.id/jmh/article/view/16227>

44 H.K. Martono Pengantar Hukum Udara Nasional dan Internasional, PT. Raja Grafindo Persada, Jakarta, 2007, (selanjutnya disingkat H.K. Martono II) h 213

${ }^{45}$ Annalisa Yahanan Norsuhaida Che Musa.Op.Cit.[247].
} 
angkutan penumpang, bagasi atau kargo, kecuali apabila pengangkut dapat membuktikan bahwa keterlambatan tersebut disebabkan oleh faktor cuaca dan teknis operasional. ${ }^{46}$ Pengaturan yang demikian memenuhi kriteria tanggung gugat yang berkonsep praduga yang bersalah dikarenakan adanya asumsi bahwa pengangkut bersalah atas kerugian tersebut dan dimungkinkannya pengangkut untuk melakukan pembuktian bahwa kerugian tidak timbul dari kesalahan pengangkut.

- Tanggung gugat mutlak (absolute liability):

Konsep tanggung gugat mutlak adalah konsep dimana pengangkut bertanggung gugat atas kerugian kerugian yang dialami oleh penumpang tanpa memperhatikan ada atau tidaknya kesalahan pengangkut yang menyebabkan kerugian tersebut. Konsep ini dapat ditemukan pada Pasal 141 UU Penerbangan yang menyatakan bahwa pengangkut wajib bertanggung gugat atas kerugian yang timbul dari meninggal dunia, cacat tetap, atau luka-luka terhadap penumpang. ${ }^{47}$ Konsep ini juga berlaku terhadap kerugian yang timbul dari hilang musnah, atau rusaknya bagasi tercatat pada kegiatan pengangkutan udara. ${ }^{48}$ Dalam konsep ini, pengangkut wajib membayar kerugian yang diderita penumpang tanpa adanya kemungkinan untuk pengangkut mengecualikan diri kewajiban tersebut. ${ }^{49}$

\section{Nilai Tanggung Gugat Codeshare Domestik}

Nilaitanggung gugatyang wajib dibayarkan oleh pengangkut kepadapenumpang yang menerima kerugian dalam penerbangan dalam bentuk apapun pada umumnya dibatasi jumlah maksimalnya oleh Peraturan Menteri Perhubungan Nomor 77 tahun

\footnotetext{
${ }^{46}$ Undang-Undang Nomor 1 Tahun 2009 tentang Penerbangan (Lembaran Negara Tahun 2009 Nomor 1, Tambahan Lembaran Negara Republik Indonesia Nomor 4956), Ps. 146.

${ }^{47}$ Ibid ps. 141 ayat (1).

48 Ibid ps. 144.

${ }^{49}$ Rhirien Adriani. 'Tanggung Gugat Pengangkut Berdasarkan Peraturan Mneteri Perhubungan Nomor 77 Tahun 2011 Tentang Tanggung Jawab Pengangkut Angkutan Udara.' Jurnal IUS Kajian Hukum dan Keadilan, Vol 3, No. 8; 2015, h 303 http://www.jurnalius.ac.id/ojs/index.php/ jurnalIUS/article/view/214.
} 
2011 tentang Tanggung Jawab Pengangkut Angkutan Udara. Namun ketentuan batas atas ganti rugi tersebut tidak dapat ditemukan pada kerugian dalam bentuk kerusakan pada bagasi kabin yang kerusakannya terjadi karena kesalahan pengangkut. Dalam keadaan tersebut, konsep nilai tanggung gugat yang berlaku adalah unlimited liability dimana nilai yang harus dibayarkan kepada penumpang adalah sesuai dengan nilai kerugian yang diderita dari rusak atau hilangnya bagasi kabin penumpang. ${ }^{50}$

\section{Penyelesaian Sengketa Ganti Rugi Penerbangan Codeshare Domestik Indonesia}

Permohonan ganti rugi tersebut merupakan sengketa yang perlu diselesaikan oleh maskapai dan penumpang. Adapun penyelesaian tersebut dapat dilakukan dalam pengadilan negeri maupun melalui penyelesaian sengketa alternatif. Penyelesaian sengketa ganti rugi melalui pengadilan negeri tersebut ditekankan oleh Pasal 176 UU Penerbangan yang menyatakan bahwa dapat diajukan gugatan ganti rugi terhadap pengangkut di wilayah Indonesia dengan menggunakan hukum Indonesia. ${ }^{51}$ Sedangkan penyelesaian sengketa alternatif dapat dilakukan melalaui lembaga yang berwenang menyelesaikan sengeketa perlindungan konsumen sesuai dengan peraturan perundang-undangan Indonesia ${ }^{52}$ berdasarkan kesepakatan kedua pihak. Adapun lembaga penyelesaian alternatif tersebut dapat dilakukan pada BPSK (Badan Penyelesaian Sengketa Konsumen) yang dibentuk oleh pemerintah dan terdapat pada tiap kota atau kabupaten. ${ }^{53}$

\section{Kesimpulan}

Berdasarkan uraian di atas dapat disimpulkan bahwa perjanjian codeshare internasional hanya dapat dilakukan apabila diperjanjikan oleh negara-negara yang berkepentingan dalam Air Service Agreement. Pada penerbangan codeshare

\footnotetext{
${ }^{50}$ Peraturan Menteri Perhubungan Nomor 77 tahun 2011 tentang Tanggung Jawab Pengangkut Angkutan Udara (Berita Negara Republik Indonesia Tahun 2011 Nomor 486) ps 4 ayat (1).

${ }^{51}$ Ibid ps. 176.

52 Penjelasan Pasal 176 Undang-Undang Nomor 1 Tahun 2009 tentang Penerbangan (Lembaran Negara Tahun 2009 Nomor 1, Tambahan Lembaran Negara Republik Indonesia Nomor 4956).

53 Undang-Undang Nomor 8 Tahun 1999 tentang Perlindungan Konsumen (Lembaran Negara Tahun 1999 Nomor 42, Tambahan Lembaran Negara Republik Indonesia Nomor 3821) Ps. 49.
} 
internasional terdapat beberapa jenis yang dapat dibedakan utamanya pada klausula yang mengatur mengenai rute yang diperjanjikan serta pengendalian inventaris antara contracting carrier serta actual carrier. Berdasarkan kedua perbedaanperbedaan perjanjian codeshare tersebut timbul dampak terhadap persaingan usaha antar maskapai peserta perjanjian codeshare. Dapat disimpulkan juga bahwa apabila terdapat kerugian yang diderita oleh penumpang pada penerbangan codeshare yang dilakukan secara internasional, maka pihak yang bertanggung gugat adalah contracting carrier dan actual carrier. Adapun jurisdiksi, nilai dan konsep tanggung gugat yang ada pada penerbangan codeshare internasional bersifat sama dengan yang ada pada penerbangan internasional yang dilakukan tidak dengan cara codeshare.

Penerbangan codeshare secara domestik masih belum ada praktiknya pada industri penerbangan di Indonesia. Meski demikian, hukum Indonesia sudah mengenal penernbangan codeshare yang dilakukan secara internasional maupun domestik. Dalam hal adanya kerugian yang diderita oleh penumpang pada penerbangan codeshare yang dilakukan secara domestik di Indonesia, hukum Indonesia mengatur bahwa pihak yang bertanggung gugat atas kerugian tersebut adalah pihak yang secara nyata melakukan pengangkutan atau actucal carrier. Adapun terhadap kerugain tersebut, penumpang atau ahli waris yang berhak dapat mengajukan upaya penyelesaian sengeketa secara non-litigasi melalui BPSK maupun secara non-litigasi melalui Pengadilan Negeri yang berwenang menyelesaikan perkara tersebut.

\section{Daftar Bacaan}

\section{Buku}

de Leon, Pablo Mendes, An Introduction to Air Law: 9th Revised Edition, The Netherlands, Kluwer Law International, 2012.

Hernoko Agus Yudha, Hukum Perjanjian: Asas Proporsionalitas dalam Kontrak Komersial, Jakarta, Kencana Prenada Group, 2009.

Harahap, M. Yahya, HUKUM ACARA PERDATA: Gugatan, Persidangan, Penyitaan, Pembuktian, dan Putusan Pengadilan, Cetakan Kesembilan, Jakarta, Sinar Grafika, 2009. 
Martono, H.K, Hukum Udara Nasional Dan Internasional Publik, Jakarta, Rajawali Pers, 2012.

Martono, H.K., Pengantar Hukum Udara Nasional dan Internasional, Jakarta, PT. Raja Grafindo Persada, 2007.

\section{Jurnal}

Adriani, Rhirien, 'Tanggung Gugat Pengangkut Berdasarkan Peraturan Mneteri Perhubungan Nomor 77 Tahun 2011 Tentang Tanggung Jawab Pengangkut Angkutan Udara.' Jurnal IUS Kajian Hukum dan Keadilan, Vol 3, No. 8; 2015,http://www.jurnalius.ac.id/ojs/index.php/jurnalIUS/article/view/214.

Adler, Nicole, 'Regulating Inter-firm Agreements: The Case of Airline Codesharing in Parallel Networks', Transportation Research Part B: Methodological, Vol 84; 2016, < https://www.sciencedirect.com/science/article/pii/ S0191261515002635>

Brueckner, Jan K., 'The economics of international codesharing: an analysis of airline alliances', International Journal of Industrial Organization, Vol 19, No 10;2001,https://www.sciencedirect.com/science/article/pii/ S0167718700000680.

Conti, Christian, "Code-sharing and Air Carrier Liability", Air and Space Law Vol. 26,No.4;2001,https://heinonline.org/HOL/LandingPage?handle=hein. kluwer/airlaw0026\&div $=6 \& \mathrm{id}=\&$ page.

Morandi, Valentina, 'Codesharing agreements by low-cost carriers: An explorative analysis', Journal of Air Transport Management, Vol 42;2 015<https://www. sciencedirect.com/science/article/abs/pii/S0969699714001380>.

Musa, Annalisa Yahanan Norsuhaida Che, 'Tanggung Jawab Pengangkut Udara Terhadap Penumpang', Mimbar Hukum, Vol 22, No. 2; 2010, <fhttps:// journal.ugm.ac.id/jmh/article/view/16227>.

Whalen, Thomas J., 'The New Warsaw Convention: The Montreal Convention', The Air and Space Law, Vol 25, No 1; 2000,< https://heinonline.org/HOL/ LandingPage?handle $=$ hein.kluwer/airlaw0025\& div=6\&id=\&page $>$.

\section{Laman}

Garuda Indonesia, "General Conditions of Carriage (Passenger and Baggage)", < https://www.garuda-indonesia.com/files/pdf/kr/COC\%20ENG.pdf $>$ diakses pada 3 Juli 2018. 
Gleave, Steed Davis, "Competition impact of airline code-share agreements", http:// ec.europa.au, Januari 2007, dikunjungi pada tanggal 6 Mei 2018.

Huaturuk, Dina Mirayanti, "Garuda Indonesia dan Sriwijaya Air Group Sepakati KerjasamaCodeshare", $<$ http://www.tribunnews.com/ bisnis/2018/05/17/garuda-indonesia-dan-sriwijaya-air-group-sepakatikerjasamacodeshare?page=all $>$, 17 Mei 2018,diakses pada tanggal 1 Juli 2018.

Kementerian Perhubungan Indonesia, "Ratifikasi Konvensi Montreal (MC) 1999, Indonesia Meningkatkan Daya Tawar di Penerbangan Internasional", http:// hubud.dephub.go.id/?id/news/detail/3019, 16 Februari 2017, dikunjungi pada tanggal 30 Juni 2018.

Klinik Hukumonline, "Kekuatan Hukum Penjelasan atas Undang Undang”, <http:// www.hukumonline.com/klinik/detail/cl3276/kekuatan-hukum-penjelasanatas-undang-undang>, 30 Januari 2012, diakses pada tanggal 3 Juli 2018.

SriwijayaAir,"SyaratdanKetentuan”, $<$ https://sriwijayaair.co.id/SJ/Termcondition $>$ diakses pada 6 Juli 2018.

Szakal, Arpad, "Interline and Code-share Agreements", http://www.aviationlaw.eu/ wp/wp-content/uploads/2013/09/Interline-and-code-share-agreements.pdf ， dikunjungi pada tanggal 4 Mei 2018.

\section{Perundang-undangan dan Perjanjian Internasional}

Undang-Undang Nomor 8 Tahun 1999 tentang Perlindungan Konsumen (Lembaran Negara Tahun 1999 Nomor 42, Tambahan Lembaran Negara Republik Indonesia Nomor 3821).

Undang-Undang Nomor 1 Tahun 2009 tentang Penerbangan (Lembaran Negara Tahun 2009 Nomor 1, Tambahan Lembaran Negara Republik Indonesia Nomor 4956).

Peraturan Menteri Perhubungan Nomor 77 tahun 2011 tentang Tanggung Jawab Pengangkut Angkutan Udara (Berita Negara Republik Indonesia Tahun 2011 Nomor 486) .

Peraturan Menteri Perhubungan Nomor 185 tahun 2015 tentang Standar Pelayanan Penumpang Kelas Ekonomi Angkutan Udara Niaga Berjadwal Dalam Negeri (Berita Negara Republik Indonesia Tahun 2015 Nomor 1823).

Convention on International Civil Aviation 1944, Opened for Signature 7 Desember 1944, 15 UNTS 295 (entered into force 4 April 1947). 
Convention for the Unification of Certain Rules for International Carriage by Air, Opened for Signature 28 Juli 1999, 2242 UNTS 309 (entered into force 4 November 2003).

\section{Lain-lain}

ICAO, 'Doc 9626 - Manual on the Regulation of International Air Transport'.

ICAO, "Revision of limits of liability under the Montreal Convention of 1999", Ref. LE 3/38.1-09/87

HOW TO CITE: Alfan Zakianto, ‘Aspek-Aspek Hukum Dalam Penerbangan Codeshare Internasional Dan Domestik Di Indonesia' (2018) Vol. 1 No. 1 Jurist-Diction. 